\title{
TATA KELOLA PEMERINTAHAN KOLABORATIF DALAM PENGEMBANGAN PARIWISATA DI KABUPATEN KEPULAUAN SULA
}

\author{
Kedasi Silayar*); Ika Sartika; Deti Mulyati \\ Pascasarjana Institut Pemerintahan Dalam Negeri Jakarta \\ *)email: silayarkedasi@gmail.com
}

Paper Accepted: 30 Juni 2021 Paper Reviewed: 01-08 Juli 2021 Paper Edited: 09-16 Juli 2021 Paper Approved: 19 Juli 2021

\begin{abstract}
ABSTRAK
Penelitian ini bertujuan untuk mengetahui tata kelola pemerintahan kolaboratif dalam pengembangan pariwisata di Kepulauan Sula. Penelitian ini menggunakan teori Edward DeSeve dan teori lain yang relevan dengan kolaborasi untuk analisis masalah. Kajian ini merupakan penelitian kualitatif deskriptif dengan pengumpulan data melalui wawancara mendalam, observasi dan dokumentasi. Studi menunjukkan bahwa konsep collaborative governance yang di tawarkan terdiri atas delapan dimensi, yaitu: (1) network structure: struktur jaringan yang memungkinkan partisipasi aktif para stakeholder dalam network. struktur jaringan tidak berbentuk hirarki, namun lebih cenderung flat dan tidak monopoli (2) Commitment to a common purpose: perhatian institusi pemerintah terhadap upaya pengembangan pariwisata masih kurang dalam pelaksanaan, pembangunan, pembinaan dan rendahnya aktivitas kolaborasi (3) trust among the participants: dengan adanya kepercayaan atas informasiinformasi dari setiap stakeholder dalam pengembangan pariwisata dan memiliki hubungan profesional (4) Governance: ketegasan siapa yang bukan stakeholder belum tergambar dengan jelas karena kolaborasi yang terjalin belum ada kesepakatan/peraturan tertulis terkait kerjasama secara spesifik membentuk keanggotaan (5) Access to authority: semua stakeholder sudah mengetahui tugas dan kewajiban masing-masing namun dalam komunikasi antar stakeholder masih sulit karena ada beberapa tempat wisata yang jaringan internetnya masih dalam perbaikan (6) Distributive accountability/responsibility: dalam pengembangan pariwisata laporan pertanggung jawaban dilakukan berbeda-beda untuk setiap stakeholder (7) Information sharing: berbagi informasi harus perlu ditingkatkan demi berkembangnya pariwisata yang lebih baik (8) Access to resources: serta dukungan sumberdaya dari pemerintah terutama untuk sumber daya manusia dan teknis terkait infrastruktur yang dimiliki masih lemah pada dinas pariwisata serta terbatasnya tenaga teknis dan ahli dalam pendampingan serta perbaikan sarana prasana.
\end{abstract}

Kata Kunci : Collaborative Governance; Pengembangan Pariwisata

\section{PENDAHULUAN}

Indonesia merupakan wilayah yang memiliki kondisi geografis dengan karakteristik wilayah kepulauan. Pulau - pulau yang tersebar di seluruh indonesia memiliki kultur kebudayaan yang beraneka ragam dan tersebar di bebagai daerah, merupakan ciri khas dan daya tarik yang dimiliki indonesia. Hal tersebut menjadi salah satu potensi besar di Indonesia Khususnya bidang Pariwisata.

Pariwisata telah berkembang sebagai sebuah realita yang menyentuh berbagai dimensi sosial, budaya, ekonomi, politik, agama, teknologi dan ekologi. Secara empirik, dalam angka perkembangan pariwisata secara keseluruhan dimensi itu berinteraksi secara baik dan bergerak secara dinamik. Aspek yang 
mendapat perhatian paling besar yang dianggap penting ialah aspek ekonomisnya, artinya untuk melakukan perjalanan orang harus mengeluarkan biaya, yang diterima oleh orang orang yang menyelenggarakan angkutan, menyediakan bermacam - macam jasa, atraksi kesenian, budaya dan lain - lain.

Pospek perkembangan pariwisata di indonesia sangat cerah, hal ini ditunjang oleh kekayaan alam dan budaya yang beragam disetiap daerah yang menjadi daya tarik tersendiri bagi pariwisata di indonesia. Dari sektor pariwisata ini mampu meningkatkan devisa negara khususnya bagi daerah yang mampu mengelola sektor pariwisata dangan baik sebagai upaya peningkatan otonomi daerah. Oleh sebab itu pariwisata dapat di pandang sebagai salah satu sektor yang dapat dijadikan sebagai faktor pendukung dari berbagai pengembangan kualitas pembangunan dan perekonomian daerah. Selain itu melalui pengembangan sektor pariwisata, dapat meningkatkan dan perekonomian masyarakat.

Undang - undang Nomor 23 Tahun 2014 tentang pemerintahan daerah menjelaskan bahwa pemerintah daerah berhak dalam mengatur urusan pilihan disesuaikan dengan potensi yang dimiliki oleh masing - masing daerah. Dengan demikian pemerintah daerah memiliki kewajiban untuk megatur potensi pariwisata yang dimiliki daerahnya. Berbagai potensi wisata yang dapat dikembangkan dan menjadi andalan dalam suatu wilayah, seharusnya terus dibenahi dan dipelihara dengan baik. Untuk itu diperlukan adanya bebagai kebijakan yang diambil oleh pemerintah daerah khususnya bidang pariwisata sesuai dengan kewenangan otonomi yang dimilikinya.

Pemerintah telah mengeluarkan UU Nomor 10 Tahun 2009 tentang Kepariwisataan, dengan adanya aturan ini maka pengembangan potensi pariwisata di daerah harus berpedoman kepada aturan tersebut. Selain itu juga terdapat aturan operasional yang disebutkan dalam UU Nomor 10 tahun 2009 dimana kepariwisataan yang harus dijadikan pedoman operasional kepariwisataan bagi daerah yaitu induk pembangunan pariwisata. Rencana induk pariwisata ini disusun berjenjang mulai dari tingkat nasional sampai dengan Kabupaten/Kota.

Provinsi maluku utara yang di beri gelar sebagai "Moluku Kie Raha" yang artinya "empat gunung" adalah satu daerah di indonesia yang berciri khas kepulauan, dan memiliki banyak potensi obyek wisata yang tersebar hampir di seluruh darah Kabupaten/Kota. Potensi pariwisata yang dimiliki masih bersifat alami, seperti panorama pantai, laut, hutan dan keanekaragaman budaya masyarakat sebagai warisan dari leluhur, sehingga daerah ini menarik untuk di kunjungi oleh para wisatawan.

Kabupaten Kepulauan Sula (Kepsul) adalah salah satu kabupaten di Provinsi Maluku Utara. Daerah yang sebelah utara berbatasan dengan laut Banda, Selatan dengan Laut Seram, Barat dengan laut Maluku, dan timur dengan Selawesi Tengah. Jarak dari kota Ternate ke Sanana adalah sekitar $284 \mathrm{~km}$ yang dapat ditempuh melalui penerbangan udara dan pelayaran laut. Kepulauan Sula juga memiliki banyak potensi pada sektor pariwisata dengan panorama yang indah yang tersebar di 12 (kecamatan) berdasarkan data yang di peroleh dari Dinas Pariwisata Dan Kebudayaan Kabupaten Kepulauan Sula.

Berdasarkan Sumber: Dinas Kebudayaan Dan Pariwisata Tahun 2019. menunjukkan bahwa objek wisata yang dimiliki kabupaten kepulauan sula sangatlah banyak, dimana terdapat 32 wisata bahari, 9 wisata budaya dan 23 wisata minat khusus.

Meskipun memiliki potensi alam yang baik, namun pengembangan belum dilakukan secara optimal. Proses pengembangan pariwisata yang di selenggarakan oleh Pemerintah kabupaten Kepulauan Sula mengalami berbagai kendala dalam pelaksanaannya karena masih minimnya transportasi pendukung akses menuju obyek wisata. Keterbatasan sumber daya manusia dalam pengembangan obyek wisata, dan masih memerlukan sentuhan peningkatan sarana dan prasarana infrastruktur yang menunjang pengembangan pariwisata. Hal itu dapat dilihat dari jumlah kunjungan wisatawan, baik wisatawan lokal (domestik) maupun kunjungan wisatawan manca negara yang tertarik untuk mengunjungi kawasan objek wisata di kabupaten kepulauan sula.

Kondisi jalan di Kabupaten Kepulauan Sula 3 (tiga) tahun terakhir dapat dilihat pada tabel berikut: 
Tabel 1

Kondisi Jalan Di Kabupaten Kepulauan Sula

\begin{tabular}{|c|c|c|c|c|}
\hline \multirow{2}{*}{ Tahun } & \multicolumn{4}{|c|}{ Kondisi Jalan } \\
\cline { 2 - 5 } & Baik & Sedang & Rusak Ringan & Rusak Berat \\
\hline 2017 & $23 \%$ & $29,27 \%$ & $27,5 \%$ & $20,68 \%$ \\
\hline 2018 & $47 \%$ & $12,34 \%$ & $7,26 \%$ & $24,40 \%$ \\
\hline 2019 & $40 \%$ & $12 \%$ & $23,50 \%$ & $24,50 \%$ \\
\hline
\end{tabular}

Sumber : Sula dalam angka 2019

Tabel di atas menunjukkan bahwa kondisi jalan di Kabupaten Kepulauan Sula merupakan salah satu faktor penghambat dalam pengembangan pariwisata di kabupaten kepulauan sula. Karena jalan juga merupakan prasarana penunjang untuk akses transportasi menuju ke tempat-tempat wisata. Bupati Kepulauan Sula, Hendrata Thes menyebutkan bahwa kondisi seperti ini menyebabkan pengembangan sektor pariwisata di Kepulauan Sula masih belum memberikan kontribusi yang signifikan bagi daerah dalam peningkatan perekenomian masyarakat Kepulauan Sula (Kompas; 2019).

Dalam wawancara dengan bapak Arifin seorang masyarakat yang berstatus sebagai penjaga Benteng Vander Lakting yang menyatakan bahwa kepulauan sula masih memiliki keterbatasan sarana dan prasarana dalam menyiapkan fasilitas pendukung baik sarana dan prasarana yang memadai sebagai salah satu prasarat untuk menarik wisatawan untuk mengunjungi objek wisata tersebut. Dan masih terbatasnya sumberdaya manusia yang di harapkan dapat membantu mengelola dan mengembangkan objek wisata yang potensial. Demikian juga kurangnya kesadaran masyarakat dalam berpartisipasi menjaga kelestarian objek wisata yang ada dan memanfaatkan potensi wisata yang ada

Menindak lanjuti wacana tersebut diatas permasalahan ini, membutuhkan peran serta berbagai pihak atau stakeholders yang secara bersama-sama melakukan pemerintahan kolaborasi (collaborative governance).

Menurut Ansell dan Gash (2007) pemerintahan kolaborasi (collaborative governance) adalah cara sebuah pemerintahan yang mengatur suatu atau lebih lembagalembaga publik pemangku kepentingan non pemerintahan dalam proses pengambilan keputusan secara kolektif yang bersifat formal, berorientasi pada konsensus, dan musyawarah yang bertujuan untuk membuat atau melaksanakan kebijakan publik atau mengelola program atau aset publik.
Pendapat tersebut didukung dengan Emerson (2011:2) yang menyatakan pemerintahan kolaborasi (collaborative governance) sebagai proses dan struktur pengambilan keputusan kabijakan publik dan manajemen yang melibatkan orang-orang secara konstruktif pada batas-batas lembaga-lembaga publik, tingkat pemerintahan, dan masyarakat, swasta dan sipil untuk melaksanakan kepentingan umum yang tidak bisa dicapai jika dilakukan satu pihak saja.

Konsep collaborative governance sendiri mencakup keterlibatan institusi-institusi mana saja yang tengah memulai usaha kerja sama, dan apa inisiatif dari masing-masing institusi (stakeholders) dalam menentukan/mendefinisikan tujuan, menilaihasil, menyebabkan perubahan, dan sebagainya. Dalam hal ini siapa yang memulai melakukan inisiatif bisa dilihat melalui tiga aspek. Pertama, inisiatif pasti bermula dari pemain/pelaku yang memiliki tujuan untuk kepentingan publik yang lebih besar. Kedua, masing-masing stakeholders atau institusi yang berkolaborasi harus memiliki peran dalam menentukan tujuan-tujuan kolaborasi. Ketiga, hubungan diantara institusi-institusi yang terlibat harus bersifat strategis, artinya bahwa setiap institusi dalam melakukan tindakan selalu bisa dilihat secara transparan dan yang lainnya memberikan respon terhadap transparansi tersebut (Donahue dalam Sudarmo,2011).

Melihat kondisi pengembangan kepariwisataan di Kepulauan Sula dengan uraian dan masalah-masalah tersebut di atas, sangat menarik kiranya ditelaah lebih lanjut bagaimana kolaborasi pemerintahan dalam pengembangan pariwisata yang sekarang ini menjadi tanggung jawab pemerintah daerah melalui penelitian ilmiah dengan judul "Tata Kelola Pemerintahan Kolaboratif (Collaborative governance) Dalam Pengembangan Pariwisata Di Kabupaten Kepulauan Sula".

\section{Perumusan Masalah}

Berdasarkan penjelasan pada pendahuluan diatas, maka dalam penjabaran permasalahan 
tersebut akan dipandu melalui pertanyaanpertanyaan sebagai rumusan masalah, yaitu;

1. Bagaimana tata kelola pemerintahan kolaboratif dalam pengembangan pariwisata di Kabupaten Kepulaun Sula?

2. Bagaimana Kolaborasi yang ideal dalam pengembangan pariwisata di kabupaten kepulauan Sula?

\section{Tujuan Penelitian}

Tujuan penelititan merupakan suatu kesatuan yang singkron dengan perumusan masalah diatas. Adapun tujuan penelitiannya adalah sebagai berikut;

1. Mengetahui tata kelola pemerintahan kolaboratif dalam pengembangan pariwisata di Kabupaten Kepulauan Sula.

2. Mengetahui kolaborasi yang ideal dalam pengembangan pariwisata di Kabupaten Kepulauan Sula.

\section{Tinjauan Teoritis}

\section{Teori Collaborative Governance}

Dalam meningkatkan pelayanan kepada masyarakat di sektor pengembangan pariwisata, pemerintah tidak dapat menjalankan pekerjaannya secara indepent, perlu adannya kerjasama yang dilakukan oleh pemerintah dengan melibatkan sektor publik dan masyarakat. Kolaborasi menjadi kunci keberhasilan pemerintah pada era reformasi birokrasi, karena dengan hal tersebut dapat membangun harmonisasi dan sinergi cara kerja yang harus dilakukan serta membentuk suatu hubungan yang berkesinambungan.

Wildavsky sebagaimana dikutip Wanna mengatakan bahwa kolaborasi dan koordinasi melibatkan 6 (enam) dimensi yang berbeda yaitu (1) kerjasama untuk membangun kesamaan, meningkatkan konsistensi dan penyelarasan kegiatan antar sektor, (2) negoisasi yang melibatkan proses dab kesiapan untuk berkompromi membuat kesepakatan, (3) peran pengawasan, memeriksa, menarik secara bersama-sama dan koordinasi secara pusat, (4) kekuasaan dan pemaksaan (5) komitmen masa depan dan perhatian, perilaku yang prospektif, perencanaan atau persiapan untuk menyelaraskan kegiatan dan (6) membagikan mitivasi internal serta komitmen pribadi pada kegiatan, keputusan, tujuan organisasi atau strategi pencapaian tujuan (Wanna;2008).

Edward Deseve dalam bukunya creating publik value using managed networks, menyebutkan bahwa terdapat delapan item penting yang bisa dijadikan ukuran keberhasilan sebuah network atau kolaborasi dalam governance, delapan item tersebut dapat mengembang pariwisata antara lain:

1. Network structure (struktur jaringan) menjelaskan tentang deskripsi konseptual suatu keterkaitan antara elemen yang sutu dengan elemen yang lain yang menyatu secara bersama-sama yang mencerminkan

2. Commitment to a common purpose (komitmen terhadap tujuan) mengacu pada alasan mengapa sebuah jaringan harus ada, yaitu karena perhatian dan komitmen untuk mencapai tujuan-tujuan yang positif.

3. Trust among the participants (adanya saling percaya diantara pelaku/peserta) didasarkan pada hubungan profesional atau sosial, yakni keyakinan bahwa para partisipan mempercayakan informasiinformasi atau usaha-usaha dari stakeholder lainnya dalam suatu jaringan untuk mencapai tujuan bersama.

4. Governance (kejelasan dalam tata kelola) kejelasan dalam tata kelola atau governance, meliputi:

a) Boundary dan exclusivity menegaskan siapa yng termasuk anggota dan bukan termasuk anggota dalam jaringan/kolaborasi.

b) Rules (aturan-aturan) menegaskan sejumlah pembatasan-pembatasan perilaku anggota dengan ancaman bahwa mereka akan dikeluarkan jika perilaku mereka menyimpang (tidak sesuai atau bertentangan dengan kesepakatan yang telah disetujui bersama). Ada aturan main yang jelas tentang apa yang seharusnya dilakukan dan apa yang seharusnya tidak dilakukan.

c) Self determination Yakni kebebasan untuk menentukan bagaimana network atau kolaborasi akan dijalankan dan siapa saja yang diijinkan untuk menjalankannya.

d) Network management Yakni berkenaan dengan resolusi penolakan/tantangan, alokasi sumberdaya, kontrol kualitas, dan pemeliharaan organisasi. Kemudia tersedia sumberdaya manusia yang memiliki kompetensi yang memenuhi persyaratan dan tersedia sumber finansial yang memadai berkesinambungan.

5. Access to authority (akses terhadap kekuasaan) 
Yakni tersedianya standar (ukuran-ukuran) ketentuan prosedur-prosedur yang jelas yang diterima secara luas.

6. Distributive accountability/responsibility (pembagian akuntabilitas/responsibilitas)

Yakni berbagai governance (penataan, pengelolaan, manajemen secara bersamasama) dan berbagai sejumlah pembuatan keputusan dengan seluruh anggota jaringan.

7. Information sharing (berbagi informasi) Yakni kemudahan akses bagi para anggota, perlindungan privacy (kerahasiaan identitas pribadi seseorang) dan keterbatasan akses bagi yang bukan anggota sepanjang bisa diterima oleh semua pihak.

8. Access to resources (akses sumber daya)

Yakni ketersediaan sumber keuangan, teknis, manusia, dan sumberdaya lainnya yang diperlukan.

Collaborative governance merupakan kegiatan banyak aktor untuk terlibat secara bersama dalam proses pengambilan keputusan. Aktor dalam bertindak didorong oleh berbagai faktor yang menjadi motivasinya. Faktor pendorong dalam pemerintahan kolaboratif setidaknya ada 4 (empat) hal yakni kepemimpinan, konsekuensi insentif yang akan diperoleh, saling ketergantungan antar aktor dan ketidakpastian.

Dari masing-masing konsep collaborative governance yang telah dijabarkan diatas alasan saya memilih konsep collaborative governance menurut Edward Deseve. dimana setiap elemen menjabarkan bagaimana seharusnya para stakeholders bekerja sama dan terlibat aktif dalam kerjasama untuk mencapai tujuan organisasi.

\section{METODE PENELITIAN}

Dalam Penelitian ini menggunakan jenis metode penelitian kualitatif deskriptif, dimana Sugiyono Berpendapat tetang metode penelitian kualitatif sebagai berikut:

"Metode penelitian kualitatif adalah motode penelitian yang digunakan untuk meneliti pada kondisi obyek yang alamiah, (sebagai lawannya adalah eksperimen) dimana peneliti adalah sebagai instrumen kunci, teknik pengumpulan data dilakukan secara trianggulasi (gabungan), analisis data bersifat induktif, dan hasil penelitian kualitatif lebih menekan pada makna dari pada generalisasi (Sugiyono, 2015)’”.
Norman K. Denkin dikutip Mudjia (2012) mendefinisikan triangulasi sebagai gabungan atau kombinasi berbagai metode yang dipakai untuk mengkaji fenomena yang saling terkait dari sudut pandang dan perspektif yang berbeda. Menurutnya, triangulasi meliputi empat hal, yaitu: (1) triangulasi metode, (2) triangulasi antar-peneliti (jika penelitian dilakukan dengan kelompok), (3) triangulasi sumber data, dan (4) triangulasi teori

Dari definisi di atas, dapat dipahami bahwa metode penelitian kualitatif dengan pola deskriptif yang dilakukan, bermaksud menggambarkan secara sistematis fakta dan karakteristik objek atau subjek yang diteliti secara tepat. Sehingga peneliti mendapatkan variasi permasalahan dan mengetahui koloborasi yang dilakukan para stakeholders dalam dalam penanganan tata kelola dalam pengembangan Pariwisata. Khususnya kolaboratif yang dilakukan oleh Dinas Kebudayaan dan Pariwisata Kabupaten Kepulauan Sula.

Dengan teknik ini diharapkan data yang dikumpulkan memenuhi konstruk penarikan kesimpulan. Kombinasi triangulasi ini dilakukan bersama dengan kegiatan dilapangan, sehingga peneliti bisa melakukan pencatatan data secara lengkap.

\section{Teknik Pengumpulan Data}

Penelitian ini dilakukan di Dinas Kebudayaan dan Pariwisata Kabupaten Kepulauan Sula Provinsi Maluku Utara. Sumber data dalam penelitian ini yaitu:

1. Data Primer Data yang diperoleh dari hasil wawancara dengan para informan.

2. Data Sekunder Dalam penelitian ini dokumen yang digunakan adalah berbagai literature-literatur yang baik dari buku, jurnal, serta media massa yang relevan dengan tujuan penelitian.

Dalam penelitian ini, teknis sampling yang dipilih adalah purposive sampling. Namun dari informasi terpilih ini didapatkan informasi mangenai narasumber lain yang memiliki data yang dapat melengkapi penelitian, sehingga peneliti juga mengunakan snowball sampling. Sesuai dengan bentuk penelitian kualitataif dan juga jenis sumber daya yang dimanfaatkan, maka teknis pengumpulan data yang digunakan dalam penelitian ini adalah:

1. Wawancara Mendalam (in-depth interview)

2. Observasi 


\section{Dokumentasi}

Guna menjamin validitas data yang dikumpulkan dalam penelitian ini digunakan teknik triangulasi sumber, yaitu mengsinkronisasi data sejenis dari beberapa sumber data yang digali informasinya. Fokus penelitian ini akan menitik beratkan pada keterlibatan pihak-pihal (stakeholders) dalam Pengembangan Pariwisata di Kepulauan Sula.

\section{PEMBAHASAN}

Pelaksanaan kebijakan pengembangan pariwisata di kabupaten kepulauan sula dalam meningkatkan pembangunan wilayah pariwisata daerah. Penelitian yang dilakukan di kabupaten kepulauan sula tepat pada 5 lokasi wisata pantai yang potensial untuk dikembangkan sebagai daerah tujuan pembangunan daerah, yaitu pantai wai ipa, pantai manaf, Pantai fatkauyon(waka), pantai waigoiyofa dan pantai fukweu(Pulau Kucing ).

Penulis akan menguraikan data yang diperoleh dari hasil wawancara dan penelitian mengenai tata kelola pemerintahan kolaborative (collaborative governance) dan pengembangan pariwisata di kabupaten kepulauan sula. Selanjutnya penulis akan menganalisis tata kelola pemerintahan kolaboratif (collaborative governance) dalam pengembangan pariwisata di kabupaten kepulauan sula dan model tata kelola pemerintahan kolaboratif yang ditawarkan dalam pengembangan pariwisata. Peneliti menggunakan delapan indikator keberhasilan menurut Deseve(203:2007),

\section{Tata Kelola Pemerintahan Kolaboratif (Collaborative Governance) Dalam Pengembangan Pariwisata Di Kabupaten Kepulauan Sula}

Pengembangan pariwisata saat ini masih menjadi sorotan karena belum di dukung dengan sarana dan prasarana pendukungnya termasuk fasilitas wisata yang representif bagi wisatawan selain itu kerja sama antara pemerintah swasta dan masyarakat masih belum efektif. Sebagaimana wujud dalam melaksanakan peraturan yg telah dikeluarkan pemerintah yaitu peraturan daerah Nomor 03 tahun 2011 tentang penataan ruang setiap provinsi dan kabupaten/kota/kawasan tertentu perlu untuk penataan ruang.

Dalam pengembangan pariwisata di kabupaten kepulauan sula dengan tujuan adalah bagaimana menyeimbangkan pembangunan di setiap wilayah maupun tingkat kecamatan melalui pembangunan dan pengembangan pariwisata maka wilayah akan mengalami tingkat pertumbuhan ekonomi.

Analisis potensi karakteristik pengembangan pariwisata pantai dilihat dari:

A. Atraksi

1. Alam

Objek wisata pantai yang berada di kepulauan sula Pantai Wai Ipa, Pantai Manaf, Pantai Waigoiyofa, Pantai Fatkauyon dan Pantai fukweu. Dari semua masih alami dan belum ada perubahan fungsi. Objek wisata pantai yang berada di kepulauan sula memiliki garis pantai berpasir putih dan ada juga yang berkrikil hitam. Dari kelima lokasi pantai ada satu lokasi pantai yang kondisi pantainya sedikit terlihat kurang baik yaitu pantai manaf, karena pantai ini telah terjadi abrasi sehingga membuat pantai ini terlihat kurang baik. Sedangkan pantai lainnya terlihat alami.

2. Upacara adat.

Objek wisata pantai yang berada di pulau sulabesi kepulauan sula adalah Pantai Wai Ipa, panta Manaf, Mantai Waigoiyofa, Pantai Fatkauyon dan Pantai Fukweu. Dari beberapa objek wisata tersebut ada satu objek wisata yang sering melakukan upacara adat yaitu objek wisata pantai fukweu.

\section{B. Aksebilitas}

1. Kondisi Jalan

Di setiap objek wisata yang berada di pulau sulabesi kepulauan sula memiliki kondisi jalan jalan yang berbeda beda, ada yang baik dan ada yang rusak. Kondisi jalan yang baik dan nyaman unruk dipakai yaitu objek wisata pantai wai ipa, karena objek wisata ini keberadaannya dekat dekat dengan pusat kota kabupaten. Sedangkan jalan menuju objek wisata pantai manaf masih terlihat kurang baik karena kondisi jalan yang sudah mulai rusak. Adapun jalan yang menuju beberapa objek wisata pantai seperti pantai waigoiyofa, pantai fatkauyon dan pantai fukweu, dari ketiga jalan ini kondisinya cukup rusak parah.

2. Sarana Transportasi

Akses menuju di beberapa objek wisata hanya satu objek wisata yang aksesnya terbilang mudah yaitu wisata pantai wai ipa, karena objek wisata ini dekat dengan pusat kota dan juga memiliki jalan yang baik. Dan objek isata ini dapat di tempuh menggunakan kendaraan beroda 
2/4. Sedangkan akses menuju wista pantai di tempat lain sedikit sulit, karena dilihat dari kondisi jalan yang rusak dan juga jarak yang begitu jauh akan tetapi masih ada yang bisa dilewati kendaraan beroda $2 / 4$.

3. Papan petunjuk arah

Dari kelima objek wisata hanya ada tiga objek wisata yang memiliki papan petunjuk arah yaitu Pantai Wai Ipa, Pantai Fatkauyon dan pantai fukweu. Selain itu pantai tersebut belum memiliki papan petunjuk arah.

\section{Amenitas}

1. Akomodasi

Di lokasi setiap objek wisata sebagian belum terdapat fasilitas akomodasi seperti Hotel, rumah makan dan tempat ibadah. Yang baru memiliki fasilitas akomodasi hanyalah wisata pantai Wai Ipa dan pantai fat kauyon.

2. Rumah makan/Warung dan Gazebo

Dari kelima lokasi yang objek wisata pantai, yang memiliki Rumah Makan/Warung yaitu objek wisata Pantai Wai Ipa, Pantai Fatkauyon dan Pantai Fukweu. Sedangkan lokasi lain apabila ingin berkunjung maka perlu embawa persediaan makanan sediri.

3. Tempat parkir

Di setiap lokasi wisata telah di sediakan ruang parkir, akan tetapi belum di alas dengan beton atau paving, dan masi beralas rumput dan ditutupi pepohonan seperti kelapa dan pohon peneduh lainnya. Pengunjung yang memarkir kendaraan harus selalu waspada karena takut akan buah kelapa yang akan jatuh mengenal kendaraannya.

\section{MCK}

Objek wisata yang telah disediakan MCK barulah objek wisata pantai wai ipa, Pantai Fatkauyon dan pantai Fukweu. Sedangakn objek wisata Pantai Manaf dan Pantai Waigoiyofa belum memiliki MCK segingga apabila wisatawan ingin melakukan hal-hal yang berbaur MCK maka wisatawan dapat langsung kerumah warga.

5. Jasa Angkutan Umum

Jasa angkutan umum menuju objek wisata berupa kendaraan beroda dua maupun beroda empat. Kendaraan beroda dua berupa ojek dan beroda empat berupa mikrolet. Dari kelima objek wisata pantai ada satu objek wisata pantai yang belum bisa dilewati oleh angkutan umum yaitu objek wisata Pantai fatkauyon. Sehingga wisatawan yang ingin berkunjung dapat dilakukan dengan kndaraan pribadi atau kendaraan laut.

Dari kelima objek wisata yang memiliki jasa komunikasi yaitu objek wisata pantai wai ipa dan pantai fukweu, sedangkan yang lain masih dalam Pembangunan,

6. Pos Keamanan dan Jasa Pemandu

Dari kelima objek wisata tersebut belum ada pos keamanan maupun jasa pemandu yang disediakan pemerintah.

Untuk mengetahui secara lebih mendalam tentang kolaborasi antara Pemerintah, Swasta dan Masyarakat maka perlu dikroscek dengan sejumlah faktor yang mempengaruhi keberhasila collaborative governance. Faktor-faktor yang dipakai dalam menganalisis kolaborasi antara Pemerintah, swasta dan masyarakat dalam Pengembangan Pariwisata di kabupaten kepulauan sula berasal dari teori Deseve (2007) yang meliputi:

\section{Network Strukture}

Tipe Network Strukture (Jenis Struktur Jaringan) ialah Konseptual atau keterkaitan antara elemen yang satu dengan yang lain menyatu secara bersama-sama yang mencerminkan unsur-unsur fisik dari jaringan yang di tandatangani. Terdapat tiga macam tipe yaitu:

a) Self governance

Yaitu network dan manajemen dilakukan oleh semua anggota. Kelebihan dari model ini bahwa semua stakeholders ikut berpartisipasi aktif, memiliki komitmen serta mudah membentuk jaringan. Kelemahan model ini tidak efisien dan pembuatan keputusan sangat terdesentralisasi sehingga sulit mencapai konsensus.

b) Lead Organization

Yaitu model ini memiliki entitas administratif (dan juga manajer yang melakukan jaringan) sebagai anggota network atau penyedia pelayanan. Sifatnya lebih tersentralisir. Kelebihannya bisa efisien dan arahan jaringan jelas

c) Network Administrative Organization (NAO)

Yaitu model ini memiliki entitas administratif secara tegas untuk mengelola jaringan, bukan sebagai 
penyedia layanan dan manejernya digaji.

Berdasarkan wawancara di lokasi penelitian yaitu Dinas Kebudayaan dan Pariwisata Kabupaten Kepulauan Sula pada tnggal 10 februari 2020. Informan Bapak Jufri Umasugi, S.Sos sebagai Kepala Dinas Kebudayaan dan Pariwisata Kabupaten Kepulauan Sula mengutarakan bahwa:

"Untuk mengembangkan pariwisata di kabupaten kepulauan sula kami dari dinas Pariwisata terus membangun komunikasi antara pemerintah, pemerintah dengan swasta dan masyarakat. Karena untuk mengembangkan pariwisata tidak bisa jika hanya dinas pariwisata yang turun tangan karena dari Dinas pariwisata masih kekurangan SDM sehingga harus ada kerja sama baik antara SKPD, Swasta dan Masyarakat. Namun kesepakatan tertulis dalam bentuk lain belum ada, semua diatur dalam peraturan pemerintah Nomor 03 tahun 2011 tentang rencana tataruang wilayah dan undang-undang nomor 10 tahun 2009 tentang kepariwisataan, dengan adanya aturan ini maka pengembangan potensi pariwisata harus berpedoman pada peraturan tersebut. Dan ini juga menjadi tugas dan tanggung jawab kami dinas pariwisata untuk terus melakukan pengembangan di kepulauan sula dan merupakan wujud dari visi misi dinas kebudayaan dan pariwisata kabupaten kepulauan sula".

Wawancara peneliti dengan Pengusaha Bidang Pariwisata pada tanggal 17 Februari 2020 yaitu Bapak Safrin Gailea mengatakan bahwa:

"Untuk mengembangkan pariwisata pastinya ada kerja sama antara pemerintah dengan kami para pengusaha. Dan peran serta pengusaha hotel dan restoran dalam bidang pariwisata sangat penting dalam pengembangan pariwisata namun dalam pengembangan pariwisata kesepakatan tertulis dalam bentuk lain belum ada karena semua di atur dalam peraturan daerah dan kami para pengusaha bekerja tanpa terikat atau bertanggung jawab terhadap pemerintah". Sedangkan Pengusaha merupakan Stakeholders yang bekerja untuk kepentingan pripadi maupun kelompoknya tanpa terikat atau bertanggungjawab terhadap pemerintah. Dalam kolabotasi, Stakeholders tetap bisa berdiri sendiri dan bekerja sesuai dengan Visi Misi masing - masing atau sesuai dengan pekerjaan bagi Stakeholders perseorangan.

Wawancara peneliti dengan tokoh masyarakat di desa wai ipa kabupaten kepulauan sula pada tanggal 20 februari 2020. Bapak Dahlan yainahu selaku kepala desa wai ipa, mengatakan bahwa:

"Untuk kerjasama dengan pemerintah ada, karna kami para tokoh masyarakat juga dilibatkan dalam pengembangan pariwisata di kepulauan sula ini. Namun dalam pengembangan pariwisata dinas kebudayaan dan pariwisata dalam membangun komunikasi baik sosialisasi atau interaksi langsung dengan para stakeholder masih belum optimal, dan dalam pengembangan pariwisata di kepulauan sula masih terdapat faktor penghambat yaitu jasa komunikasi dari beberapa tempat wisata masih belum memiliki jasa komunikasi sehingga menghambat dalam pengembangan pariwisata".

Dari beberapa objek wisata yang baru memiliki jasa komunikasi yaitu objek wisata pantai wai ipa dan objek wisata Fukweu. Sedangkan yang lain masih dalam pembangunan.

Selanjutnya wawancara peneliti dengan informan yaitu Masyarakat peneliti memilih secara random sebanyak 4 orang mengenai Tata Kelola Pemerintahan kolaboratif dalam pengembangan Pariwisata di Kepulauan Sula, Masyarakat berpendapat:

"Kolaborasi antara pemerintah dengan masyarakat setempat memang ada, namundalam tahap pelaksanaan tidak semua masyarakat dilibatkan, dan yang dilibatkan hanya masyarakat yang memiliki jasa seperti pemilik homestay, perahu motor dan masyarakat yang berdagang di sekitar tempat wisata".

Namun masing-masing stakeholders terlibat dan berpartisipasi aktif dalam network. Struktur jaringan yang ada disini tidak membentuk hirarki, namun lebih cenderung flat dan tidak ada monopoli. Semuanya setara baik dalam menjalankan hak dan kewajibannya juga terkait dengan kesempatan aksebilitasnya. Sehingga dapat disimpulkan tipe networked struktur yang ada dalam kolaborasi di sini adalah tipe self governance.

\section{Commitment To A Common Purpose (Komitmen Terhadap Tujuan)}

Kerjasama yang terjalin antara pemerintah dengan stakeholders mengacu pada alasan sebagai upaya pengembangan Pariwisata 
Kabupaten Kepulauan Sula. Hal ini dikarenakan pariwisata di kepulauan sula sangatlah banyak dan menarik yang tidak dimiliki daerah lain dan ini merupakan keunggulan yang di miliki pada sektor pariwisata. Pemerintah dalam hal ini dinas kebudayaan dan pariwisata kabupaten kepulauan sula sebagai unsur pelaksana pemerintah kabupaten yang mempunyai tugas membantu Bupati dalam melaksanakan kewenangan pemerintah di bidang pariwisata dan memiliki visi mengembangkan pariwisata Kepulauan sula sebagai Pariwisata Nasional yang berbasis pada sektor unggulan.

Dalam relita yang ada, perhatian dan komitmen dinas kebudayaan dan pariwisata kabupaten kepulauan sula mulai berkurang pada kollaborasi dalam upaya pengembangan pariwisata dimana dalam kerjasama dengan Pengusaha, Tokoh masyarakat dan masyarakat diperlukan komitmen dari masing-masing Institusi maupun perorangan.

Berdasarkan wawancara peneliti pada tanggal 10 februari 2020 kepada informan di Kantor Dinas Kebudayaan dan Pariwisata Kabupaten Kepulauan Sula Bapak Jufri Umasugi, S.Sos menjelaskan bahwa:

"Dalam mengembangkan pariwisata tentunya ada kerja sama dengan SKPD lain, terus Swasta dan Masyarakat. Pengembangan Pariwisata di kepulauan sula merupakan wujud dari Visi dan Misi Dinas Kebudayaan Pariwisata Kabupaten Kepulauan Sula Yaitu Mengembangkan Kabupaten Kepulauan Sula Sebagai Pusat Kegiatan Pariwisata Nasional Yang Berbasis Pada Sektor Unggulan Jasa Perdagangan, Pendidikan, Pariwisata Yang Bercirikan Pesisir dan Kepulauan”.

Selain itu komitmen dalam Pengembangan pariwisata bersifat top down. Komitmen pemerintah terhadap keberhasilan pengembangan pariwisata ini sangat tinggi. Semua bentuk kolaborasi diarahkan untuk mencapai tujuan yaitu mengembangkan kebupaten kepulauan sula sebagai pusat kegiatan pariwisata nasional yang berbasis pada sektor unggulan jasa perdagangan, pendidikan, pariwisata yang bercirikan pesisir dan kepulauan.

Sementara itulah hasil wawancara peneliti kepada Bapak Nur Saleh Bainuru,ST. selaku Kepala Dinas Pekerjaan Umum Kabupaten Kepulauan Sula pada tanggal 13 februari 2020, bahwa:

"Kalau kerja sama dengan dinas
pariwisata untuk pengembangan
pariwisata memang ada karena
Pemerintah kabupaten kepulauan sula

telah menetapkan pariwisata sebagai bagian dari pembangunan dan membuat kebijakan pariwisata berbasis ekonomi pembangunan untuk mendukung pengembangan pariwisata. Ini bersifat top down. Komitmen pemerintah terhadap keberhasilan pengembangan pariwisata sangat tinggi. Semua bentuk kolaborasi diarahkan untuk mencapai tujuan dalam pengembangan pariwisata dan dinas $P U$ saat ini sedang fokus melengkapi sarana prasara penunjang, seperti perbaikan jalan - jalan menuju Wisata pantai fat kauyon (tanjung waka) dan pantai Fukweu(pulau kucing) yang masih rusak".

Sedangkan untuk permasalahan perbaikan jalan sudah beberapa tahun ini belum juga selesai-selesai dan pemerintah sedang fokus memakai alat-alat berat untuk pembangunan jalan tani di kecamatan mangoli timur, kecamatan mangoli tengah dan kecamatan mangoli selatan.

Kolaborasi yang terbentuk sudah mendasar pada tujuan, Visi dan Misi yang sama jika dilihat dari sisi pemerintah. Hambatan masih ada dari sisi sarana dan prasarana, minimnya jaringan internet, sarana transportasi serta SDM yang masih terbatas dalam Pengembangan pariwisata di kabupaten kepulauan sula.

Sebagaimana yang diuatarakan dalam wawancara peneliti kepada masyarakat mengutarakan bahwa:

"Pemerintah punya komitmen untuk mengembangkan pariwisata karena ini merupakan salahsatu sumber yang bisa meningkatkan perekonomian masyarakat sekitar dan kami berharap pemerintah terus melakukan perbaikan baik infrastruktur serta melengkapi sarana dan prasarana sebagai penunjang pariwisata”.

Melihat realita dari seluruh wawancara di atas kolaborasi yang ada, komitmen perhatian institusi pemerintah terhadap upaya pengembangan pariwisata dirasa masih kurang, padahal dalam rencana kerjanya, Pemerintah (Dinas Pariwisata, dinas Perhubungan dan Dinas PU) memiliki tugas sebagai pelaksana, Pembangunan, Pembinaan, Pengembangan pariwisata. Oleh karena itu, hal ini bisa dipandang sebagai perwujudan rendahnya efektivitas kolaborasi. 


\section{Tipe Trust Among The Participant (adanya saling percaya diantara pelaku/ peserta)}

Tipe ini dasarkan pada hubungan profesional atau sosial, yakni keyakinan bahwa para partisipan mempercayakan informasiinformsi atau usaha-usaha dari stakeholders lainnya dalam suatu jaringan untuk mencapai tujuan bersama. Dalam sebuah kolaborasi sangat diperlukan kepercayaan antara Pemerintan dengan Swasta dan Masyarakat harus ada rasa saling percaya satu sama lain.

Hasil wawancara peneliti kepada informan yaitu Jufri Umasugi, S.Sos selaku Kepala Dinas Kebudayaan dan Pariwisata Kabupaten Kepulauan Sula mengutarakan bahwa:

"Rasa percaya terhadap kolaborasi dalam pengembangan pariwisata di kepulauan sula sangat tinggi karena kita terus melakukan sosialisasi, pembinaan terhadap masyarakat desa wisata, pengawasan serta kita terus membangun komunikasi dengan swasta maupun masyarakat. Hal ini dibuktikan dengan kolaborasi antara stakeholder dalam menyelenggarakan festival Tanjung Waka pantai fatkauyon 2019 dan ini merupakan salah satu kegiatan yang sukses serta menarik para wisatawan untuk berkunjung ke kepulauan sula".

Dari sumber data Dinas kebudayaan dan Pariwisata kabupaten kepulauan sula bahwa pengunjung atau wisatawan pada tahun 2015 dengan jumlah 13425 jiwa dan pada tahun 2016 smpai dengan tahun 2019 pengunjung atau wisatawan semakin meningkat menjadi 29085 jiwa. Hal ini menunjukkan bahwa pariwisata di kabupaten kepulauan sula sangat di minati akan tetapi masih ada keluhan dari wisatawan terkait sarana prasara pendukung yakni fasilitas yang layak bagi wisatawan seperti tempat parkir, MCK, Pos Keamanan/jasa pemandu, dan transportasi wisata.

Rasa saling percaya antara pengusaha dengan pemerintah dalam mengembangkan pariwisata di kepulauan sula ini kami sepenuhnya percaya.

Terkait dengan kepercayaan adanya saling percaya antara stakeholders dalam kolaborasi untuk mengembangkan pariwisata di kabupaten kepulauan sula sudah ada kepercayaan. Para stakeholders memiliki hubungan profesional dan sosial yang baik karena mereka menyadari akan pentingnya peran masing-masing yang saling terkait untuk tujuan bersama.

Masyarakat mengutarakan kepada peneliti bahwa masyarakat percaya kepada pemerintah namun ada masyarakat tidak memiliki kepercayan terhadap pemerintah. dalam proses pengembangan pariwisata dan ada komunikasi antara pemerintah dan masyarakat namun dalam proses tidak semua masyarakat dilibatkan, hanya masyarakat yang memiliki jasa pariwisata.

Dengan kepercayan atas informasiinformasi atau data dari setiap stakeholders dalam pengembangan Pariwisata Kebaupaten Kepulauan Sula sudah ada kepercayaan. Para stakeholders memiliki hubungan profesional dan sosial yang baik karena mereka menyadari akan pentingnya peran masing-masing yang saling terkait untuk tujuan bersama.

\section{Governance (kejelasan dalam tata kelola)}

Tipe ini didasarkan pada kesepakatan atau kontrak tertulis secara spesifik, ketegasan siapa pihak-pihak terkait (stakeholder) yang termasuk dalam anggota kolaborasi dan yang bukan dalam kolaborasi tersebut.

Hasil wawancara peneliti kepada informan di Kantor Dinas Kebudayaan dan Pariwisata kabupaten kepulauan sula pada tanggal 10 februari 2020. Menurut informan Bapak Jufri Umasugi, S.Sos. selaku Kepala Dinas Pariwisata kabupaten kepulauan sula mengutarakan bahwa:

"Kesepakatan tertulis dalam bentuk kontrak tertulis belum ada, karena di atur dalam peraturan Daerah Kabupaten kepulauan sula pasal 2. (1) program pembangunan daerah kabupaten kepulauan sula periode 2005 - 2025 dilaksanakan sesuai dengan RPJPD kabupaten kepulauan sula. (2) rincian dari program pembangunan daerah sebagaimana dimaksud pada ayat (1) terdapat lampiran peraturan daerah ini. Namun untuk kejelasan siapa saja yang menjadi anggota kolaborasi sudah ada kejelasan yaitu Pemerintah, swasta dan masyarakat. dan semиa terlibat dalam kolaborasi pengembangan pariwisat".

Sementara itu menurut tokoh masyarakat kepada peneliti yaitu bapak Dahlan Yainahu selaku kepala desa wai ipa kabupaten kepulauan sula pada tangga 20 februari 2020 mengatakan bahwa:

"Kesepakatan tertulis antara pihak-pihak terkait dalam bentuk kontrak tertulis belum ada, karena semuanya diatur dalam peraturan Daerah siapa saja yang masuk dalam pihak-pihak stakeholder dalam 
melakukan Kolaborasi untuk
mengembangan pariwisata”.

Masyarakat mengutarakan kepada peneliti bahwa tidak ada kesepakatan tertulis dalam kolaborasi untuk mengembangkan pariwisata karena masyarakat bukan pihak pemangku kepentingan namun sebagai pengguna kebijakan dalam pengembangan pariwisata.

Hasil wawancara diatas menunjukkan ketegasan siapa yang bukan stakeholders belum tergambar dengan jelas mengingat kolaborasi yang terjalin belum ada kesepakatan/peraturan tertulis terkait kerja sama secara spesifik membentuk keanggotaan dalam pengembangan pariwisata khususnya 5 tempat wisata yakni Wisata Pantai Wai ipa, wisata pantai manaf, wisata pantai fatkauyon(tanjungwaka), wisata pantai waigoiyofa dan wisata pantai fukweu(Pulau kucing).

Namun dalam pengembangan masih ada hambatan yakni kurangnya sarana parasarana, jumlah SDM yang terbatas, kurangnya tingkat kesadaran masyarakat. Sehingga kolaborasi yang terjadi belum memenuhi aspek kejelasan governancenya.

\section{Access to autority (akses terhadap otoritas)}

Tipe ini menjelaskan tersedianya standar (ukuran-ukuran) persyaratan dan ketentuan prosedur - prosedur yang jelas yang diterima secara luas.

Menurut informan Bapak Jufri Umasugi, S.sos Selaku Kepala Dinas Kebudayaan dan Pariwisata Kabupaten Kepulauan Sula. Berdasarkan wawancara di kolasi penelitian pada tanggal 10 februari 2020 mengutarakan bahwa:

"Untuk Prosedur Pengembangan sudah di ketahui oleh seluruh kalangan masyarakat, karena sudah dilakukan sosialisasi secara tatap muka akan tetapi belum dapat di akses melalui jaringan internet oleh sebagian masyarakat desa wisata yang belum meliki jasa komunikasi. Dari beberapa objek wisata yang baru memeiliki jasa komunikasi yaitu objek wisata pantai wai ipa dan pantai fukweu, ini karena pantai wai ipa dekat dengan pusat kota. Dan pantai fukweu untuk pembangunan jaringan sdh selesai sedangkan yang lain masih dalam tahap pembangunan".

Aksebilitas merupakan kebutuhan yang sangat penting untuk pengembangan pariwisata dimana aksebilitas yang kurang memadai akan menjadi hambatan bagi pengembangan kawasan wisata. Jaringan, jalan dan alat transportasi merupakan potensi yang perlu dipertimbangkan dalam suatu wilayah perencanaan karena sarana dan prasara ini sangat penting untuk memperlancar kegiatan.

Menurut Kepala Desa Fukweu kecamatan Sanana Utara sebagai informan peneliti Yaitu Bapak Safidin Gamkonora pada tanggal 20 februari 2020 mengutarakan Bahwa:

"Proses pelaksanaan pengembangan Pariwisata sudah diketahui secara terbuka karena diinformasikan bahwa dinas kebudayaan dan pariwisata sudah melakukan sosialisasi kepada seluruh SKPD, Swasta dan masyarakat. Namun belum dapat di akses secara luas oleh masyarakat kabupaten kepulauan sula karena keterbatasan jaringan. Tugas dan tanggung jawab sudah jelas sebagai salah satu stakeholder dalam pengembangan pariwisata dikepulauan sula".

Masyarakat mengutarakan bahwa prosedur sudah mengetahui, namun beberapa hal yang masih dirasa sulit adalah Komunikasi dengan dinas kebudayaan dan pariwisata dalam prosedur pengembangan pariwisata dikabupaten kepulauan sula. Dari kacamata masyarakat harus adanya sosialisasi serta pendekatan dari dinas kebudayaan dan pariwisata dengan masyarakat desa pariwisata sehingga mempermudah proses komuniasi dan meningkatkan kesadaran masyarakat akan pentingnya pariwisata dan masyarakat juga tau dan mengerti tugas dan kewajiman masyarakat dengan jelas .

Dalam kolaborasi ini dapat di simpulkan bahwa, semua stakeholders sudah memahami bagaimana alur prosedurnya dengan jelas, juga mengetahui tugas dan kewajiban mereka masing-masing. Namun dalam komunikasi antar stakeholders yang masih sulit karena ada beberapa tempat wisata yang jaringan internetnya masih dalam tahap pembangunan.

\section{Distributive accountability / \\ responsibility (pembagian akuntabilitas / responsibilitas) \\ Tipe ini didasarkan pada hubungan berbagi} sejumlah pembuatan keputusan dengan seluruh anggota jaringan, artinya berbagi tanggung jawab untuk mencapai hasil atau tujuan yang diinginkan.

Berdasarkan wawancara dilokasi penelitian yaitu Dinas Kebudayaan dan Pariwisata Kabupaten Kepulauan Sula pada tanggal 10 februari 2020. Menurut informan bapak Jufri Umasugi, S.Sos selaku Kepala Dinas 
Kebudayaan dan Pariwisata Kabupaten Kepulauan Sula mengutarakan bahwa:

"Pembagian tanggung jawab Dinas Kebudayaan dan Pariwisata Kepulauan Sula sudah jelas diatur dalam Peraturan Bupati Nomor 43 tahun 2018 Tentang Organisasi dan Tata Kerja Dinas Kebudayaan dan Pariwisata sebagaimana dijelaskan pada Pasal 7 ayat 2 yaitu bidang Pariwisata dan Ekonomi Kreatif dipimpin oleh seorang kepala bidang yang berkedudukan dibawah dan bertanggung jawab kepada Kepala Dinas dan Pasal 8 ayat 1 yaitu mengumpulkan dan menganalisa data destinasi wisata, menyususun bahan petunjuk teknis lingkup destinasi pariwisata sebagai pedoman pelaksanaan tugas, melaksanakan inventarisasi destinasi pariwisata serta pembinaan dan pengelolaan destinasi pariwisata, melaksanakan kegiatan lingkup pembinaan destinasi pariwisata yang meliputi pembinaan terhadap daya tarik dan objek wisata, melakukan evalusi dan pelaporan pelaksanaan lingkup destinasi pariwisata, membuat telahan staf bahan pertimbangan perumusan kebijakan lingkup destinasi pariwisata, melaksanakan pengawasan dan pengendalian lingkup destinasi pariwisata, melakukan monitoring, evalusi dan pelaporan lingkup destinasi pariwisata”.

Sementara itu, menurut informan kepada peneliti yaitu Ibu Yani Weu selaku pengusaha di kabupaten kepulauan sula pada tanggal 17 februari 2020 mengatakan bahwa:

"Dalam berbagi informasi terkait pariwisata kami rasa cukup transparan dan proses pembagian informasi terkait pengembangan pariwisata melalui sosialisasi oleh dinas pariwisata. Pembagian tanggung jawab di sektor pemerintah sudah ada dan jelas, karena di atur oleh Peraturan daerah terkait. Bentuk laporan pertanggung jawaban dari level bawah ke level di atasnya juga sudah jelas karena di atur oleh peraturan Daerah terkait”.

Menurut Kepala Desa Fukweu sebagai informan peneliti yaitu Bapak Safidin Gamkonora pada tanggal 20 februari 2020 di kantor desa Fukweu kecamatan sanana Utara mengutarakan bahwa:

"Pembagian tanggung jawab di kantor desa Wai Ipa Kecamatan Sanana Kabupaten Kepulauan Sula sudah jelas, karena di atur dalam Peraturan pemerintah Nomor 03 Tahun 2011 tentang rencana dan tataruang wilayah".

Bagi masyarakat proses pembuatan keputusan serta mengambil keputusan terkait pariwisata di kepulauan sula ialah pemerintah dan tugas masyarakat menyetujui segala keputusan yang di buat oleh pemerintah.

Hasil wawancara diatas dapat ditarik kesimpulan bahwa laporan pertanggung jawaban disini dilakukan secara berbeda-beda untuk setiap stakeholdernya yakni tergantung dengan pihak yang membawahi. Dalam pelaksanaannya masih ditemukan kelemahan yakni kolaborasi Antar Stakeholders masih belum efektif.

\section{Information Sharing (berbagi informasi)}

Tipe ini menjelaskan kemudahan akses bagi para anggota, perlindungan privasi (kerahasiaan identitas pribadi seseorang) dan keterbatasan akses bagi yang bukan anggota sepanjang bisa diterima oleh semua pihak.

Sebagaimana berdasarkan Wawancara di lokasi penelitian yaitu Dinas Kebudayaan dan Pariwisata Kabupaten Kepulauan Sula pada tanggal 10 Februari 2020 menurut Informan Bapak Jufri Umasugi S.Sos selaku Kepala Dinas Kebudayaan dan Pariwisata Kabupaten Kepulauan Sula mengutarakan bahwa:

"Dalam berbagi informasi sudah terbentuk kepercayaan di antara anggota kolaborasi dan untuk mengembangkan pariwisata tidak ada informasi yang kami smbunyikan semua dilakukan dengan transparan oleh semua pihak dan proses pembagian informasi yang kami lakukan dengan bentuk persuratan secara formal ke SKPD yang terlibat serta swasta dan juga masyarakat. Serta kami juga melakukan sosialisasi serta muasyawarah dengan masyarakat desa wisata”.

Berdasarkan wawancara dengan Kepala desa Fukweu kecamatan sanana Utara Kabupaten Kepulauan Sula pada tanggal 20 februari 2020 mengatakan bahwa:

"Untuk proses pembagian informasi dari dinas pariwisata kepada kami yaitu dengan melaui persuratan, kemudian juga dilakukan musyawarah jika ada hal yang harus di bahas terkait pariwisata dan dalam berbagi informasi sudah terbentuk rasa saling percayaantara pemangku kepentingan". 
Hasil wawancara peneliti kepada masyarakat yaitu proses pembagian informasi dari pemerintah terkait pengembangan pariwisata tentunya dengan sosialisasi, menyurat ke tokoh masyarakat dan kemudian tokoh masyarakat mengadakan pertemuan dengan masyarakat.

Di sini information sharing (berbagi informasi) benar-benar dilakukan antar stakeholders. Semua stakeholders saling mengisi dan melengkapi informasi dan data satu sama lain. Masing-masing stakeholders menyatakan adanya kepercayaan terkait informasi yang diberikan oleh stakeholders lainnya dan mereka juga saling membantu.

\section{Access to resources (akses sumber daya)}

Tipe ini menjelaskan adanya ketersediaan sumber keuangan, teknis, manusia, dan sumberdaya lainnya yang diperlukan.

Dalam rangka mencapai tujuan pokok dari tatakelola pemerintahan kolaboratif dalam pengembangan pariwisata di kabupaten kepulauan sula. stakeholders sudah berusaha dalam menyediakan sumberdaya yang dibutuhkan sebagaimana diutarakan dibawah ini oleh beberapa informan dimasing-masing instansi.

Berdasarkan wawancara di lokasi penelitian yaitu Dinas Kebudayaan dan Pariwisata kabupaten kepulauan sula pada tanggal 10 februari 2020. Menurut informan Bapak Jufri Umasugi, S.Sos selaku Kepala Dinas Kebudayaan dan Pariwisata Kabupaten Kepulauan Sula mengutarakan bahwa:

"Sumberdaya dalam hal penganggaran kami dari dinas pariwisata sudah ada anggaran yang disusun untuk masingmasing unit pariwisata untuk proses menunjang kegiatan, namun hal tersebut masih kurang efektif karena permintaan anggaran pembangunan pariwisata yang tidak sesuai dengan alokasi anggaran yang diterima untuk pembangunan dan pengembangan. Sehingga berpengaruh pada tingkat keberhasilan pembangunan di lima kawasan wisata yaitu pantai wai ipa, pantai waigoiyofa, pantai manaf, pantai fatkauyon dan pantai fukweu. Dan kami juga kekurangan SDM dalam proses pengawasan di masing-masing tempat wisata".

Tabel 2

Alokasi Anggaran Pembangunan Pariwisata 2018

\begin{tabular}{|c|l|l|l|}
\hline No & \multicolumn{1}{|c|}{ Nama Lokasi } & \multicolumn{1}{|c|}{$\begin{array}{c}\text { Permintaan Anggaran } \\
\text { Pembangunan Wisata }\end{array}$} & \multicolumn{1}{c|}{ Alokasi Anggaran } \\
\hline 1 & Pantai Wai Ipa & Rp. 490.000 .000 .00 & Rp. 250.000 .000 .00 \\
\hline 2 & Pantai Manaf & Rp. 4.00 .000 .000 .00 & Rp.130.000.000.00 \\
\hline 3 & Pantai Fatkauyon & Rp. 5.50 .000 .000 .00 & Rp.240.000.000.00 \\
\hline 4 & Pantai Waigoiyofa & Rp. 2.80 .000 .000 .00 & Rp.180.000.000.00 \\
\hline 5 & Pantai Fukweu & Rp. 1.95 .000 .000 .00 & Rp.100.000.000.00 \\
\hline
\end{tabular}

Sumber: Data Dinas Kebudayaan dan Pariwisata Kabupaten Kepulauan Sula 2019.

Dari gambar tabel di atas dapat dilihat secara langsung permintaan anggaran pembangunan pariwisata yang tidak sesuai dengan alokasi anggaran yang di terima untuk pembangunan dan pengembangan. Sehingga berpengaruh pada tingkat keberhasilan pembangunan dari lima kawasan wisata di atas tersebut.

Selanjutnya wawancara peneliti dengan informan Kepala Dinas Pekerjaan Umum Kabupaten Kepulauan sula, pada tanggal 13 februari 2020 di kantor Dinas Pekerjaan Umum Kepulauan Sula Nur Saleh Bainuru,ST. Mengatakan Bahwa:

"Dari Dinas PU sudah mengarahkan semua sumberdaya yang dimiliki yaitu dengan perbaikan jalan-jalan yang rusak menuju tempat wisata untuk kemudahan para masyarakat dan wisatawan berkunjung ke tempat wisata dan tetap dilakukan sesuai dengan prosedur berdasarkan peraturan yang ada".

Menurut informan Kepala Dinas Perhubungan kepada peneliti yaitu Bapak A. Yasin Hayatudin pada tanggal 14 februari 2020 mengutarakan bahwa:

"Dinas Perhubungan sudah mengarahkan semua sumberdaya yang dimiliki dengan selalu berusaha memberikan berbagai kemudahan dalam pelayanan Perjalanan baik penyediaan tranportasi darat, laut dan udara". 
Sementara itu, menurut informan kepada peneliti yaitu Bapak Safrin Gailea selaku salah satu pengusaha di kabupaten kepulauan sula pada tanggal 17 februari 2020 mengatakan bahwa :

"untuk sumberdaya dalam pengembangan pariwisata kami dari pihak pengusaha hotel dan penginapan yang merupakan salah satu sarana dan prasarana yang melengkapi dan memudahkan proses kegiatan pariwisata di kepulauan sula selalu berusaha memberikan pelayanan yang baik serta keyamanan dan keamanan kepada setiap tamu yang datang dan yang menginap. Pelayanan yang diberikan sudah sesuai dengan prosedur dan peraturan yang ada".

Menurut kepala Desa Fukweu Kecamatan Sanana Utara Kabupaten Kepulauan Sula sebagai informan peneliti yaitu Bapak Safidin Gamkonora pada tanggal 20 februari 2020 mengutarakan bahwa:

"Sumberdaya alam yang dimiliki kabupaten kepulauan sula khususnya pariwisata ini sangat banyak dan indah namun infrastruktur, sarana dan prasarana seperti jalan, telekomunikasi, jembatan, MCK, tempat parkir dan juga transportasi wisata masih belum ada, ada sebagian tempat wisata yang sudah memiliki telekomunikasi, MCK, tempat parkir dan juga jalan yang sudah bagus akan tetapi ada tempat wisata lain yang belum memiliki fasilitas yang sama sehinga perkembangan pariwisata di kepulauan sula ini bisa dikatakan belum optimal, sehingga infrastruktur, prasarana dan prasana yang ada perlu di lengkapi”.

Masyarakat merasa pemerintah masih perlu memberikan berbagai sumber daya untuk pengembangan pariwisata di kabupaten kepulauan sula. Kondisi sumberdaya alama yang sangat bagus namun yang masih kurang yaitu SDM, sarana dan prasarana yang belum memadai.

Dalam rangka mencapai tujuan pokok dari kolaborasi, terkait tata kelola pemerintahan kolaboratif dalam pengembangan pariwisata di kabupaten kepulaun sula sudah dilakukan terbukti bahwa adanya anggaran-anggaran dalam setiap instansi masing-masing stakeholders. Namun sumberdaya manusia dan teknis terkait perbaikan infrastruktur yang dimiliki masih lemah terutama pada Dinas Kebudayaan dan Pariwisata, terbukti dengan adanya fakta bahwa kurangnya SDM pada dinas pariwisata serta terbatasnya tenaga teknis atau tenaga ahli dalam hal ini pendamping di setiap tempat wisata dimana instansi ini yang langsung bersentuhan atau terlibat langsung dalam pengembangan pariwisata.

\section{Kolaborasi Ideal Dalam Pengembangan Pariwisata Di Kabupaten Kepulauan Sula}

Dari penjabaran bagaimana tata kelola pemerintahan kolaboratif dalam pengembangan pariwisata di Kabupaten Kepulauan Sula dapat dilihat bahwa jenis struktur jaringan yang sesuai dalam pengembangan pariwisata di Kepulauan Sula adalah: Self Governance model, yaitu masing-masing Stakeholders berpartisipasi dalam network dan manajemen dilakukan oleh semua anggota. Kelebihan dari model ini bahwa semua stakeholders ikut berpartisipasi aktif, memiliki komitmen serta membentuk jaringan. Kelemahan model ini tidak efisien dan pembuatan keputusan sangat terdesentralisasi sehingga sulit mencapai konsensus. Stakeholders yang terlibat sedikit saja sehingga memudahkan komunikasi dan pemantauan secara intensif. Dalam kasus ini sebaiknya pemerintah bertindak sebagai inisiator pengembangan dan pengawasan.

Masing - masing aktor yang terlibat dalam pengembangan pariwisata kepulauan sula dapat dilihat dari peran setiap stakeholders dalam pelaksanaan pengembangan pariwisata. Aktor aktor yang terlibat dalam pengembangan pariwisata antara lain adalah:

a. Dinas pariwisata dan kebudayaan Kabupaten Kepulauan Sula yang berperan sebagai pebuat kebijakan dan koordinator program pemberdayaan serta pembinaan sumberdaya manusia, penyediaan sarana dan prasarana serta penyuluhan dan pengembangan pariwisata di kepulauan sula.

b. Pemerintah desa sebagai akselerator yang berperan sebagai pengelolaan fasilitas penunjang bagi pengunjung wisata seperti: pengelolaan lahan parkir objek wisata di kepulauan sula.

c. Swasta (pengusaha) memiliki peran sebagai fasilitator dalam pengembangan pariwisata, dalam hal ini swasta berkontribusi terhadap pembangunan fasilitas pelengkap objek wisata yaitu pembangunan hotel dan warung - warung makan di kawasan wisata.

d. Masyarakat sekitar kawasan pariwisata berperan dalam pengamanan wilayah kawasan wisata maupun sebagai pengelola objek wisata serta 
pemanfaatan objek wisata di kepulauan sula.

\section{KESIMPULAN}

Penelitian yang telah dilakukan di Dinas Kebudayaan dan Pariwisata Kabupaten Kepulauan Sula menghasilkan beberapa kesimpulan yaitu:

1. (Dimensi networked strukture) Struktur jaringan tidak berbentuk hirarki, namun lebih cenderung flat dan tidak monopoli dimensi ini masih perlu di tngkatkan. (Dimensi commitment to a common purpose) komitmen perhatian institusi pemerintah terhadap upaya pengembangan pariwisata di rasa masih kurang padahal dalam rencana kerjanya pemerintah memiliki tugas sebagai pelaksanan, pembangunan pembinaan, pengembangan pariwisata Oleh karena itu, dimensi ini masih perlu ditingkatkan. (Dimensi trust among the participant) Para stakeholders memiliki hubungan profesional dan sosial yang baik karena mereka menyadari akan pentingnya peran masing-masing yang saling terkait untuk tujuan bersama, sehingga dimensi ini dikatakan sudah berjalan baik. (Dimensi Governance) ketegasan siapa yang bukan stakeholders belum tergambar dengan jelas mengingat kolaborasi yang terjalin belum ada kesepakatan/peraturan tertulis terkait kerjasama secara spesifik membentuk keanggotaan dalam pengembangan pariwisata. sehingga kolaborasi belum memenuhi aspek kejelasan governance sehingga dimensi ini masih perlu ditingkatkan. (Dimensi access to autority) semua stakeholders sudah memahami bagaimana alur prosedurnya dengan jelas, Namun dalam komunikasi antar stakeholders yang masih sulit karena ada beberapa tempat wisata yang jaringan internetnya masih dalam tahap pembangunan sehingga dapat dikatakan dimensi ini masih perlu di tingkatkan. (Dimensi distributive accountability) dalam pengembangan pariwisata laporan pertanggung jawaban dilakukan berbedabeda untuk setiap stakeholdernya yakni tergantung dengan pihak yang membawahi. Dalam pelaksanaannya masih ditemukan kelemahan sehingga dimensi ini masih perlu ditingkatkan. (Dimensi information sharing) dalam pengembangan pariwisata berbagi informasi benar-benar dilakukan antar stakeholders Masing- masing stakeholders dan saling membantu sehingga dapat dikatakan dimensi ini sudah berjalan baik. (Dimensi access to resources) Tatakelola pemerintahan kolaboratif dalam pengembangan pariwisata sudah di lakukan terbukti bahwa adanya anggaran-anggaran dalam setiap instansi. Namun SDM dan teknis terkait perbaikan infrastruktur yang dimiliki masih lemah terutama pada dinas pariwisata.

2. Masing - masing aktor yang terlibat dalam pengembangan pariwisata kabupaten kepulauan sula dapat dilihat dari peran setiap stakeholder dalam pengembangan pariwisata. Beberapa stakeholder dalam pengembangan pariwisata adalah Dinas pariwisata Kabupaten Kepulauan Sula, Pengusaha Pariwisata, tokoh masyarakat dan Masyarakat. Pemerintah (Dinas Pariwisata) memiliki peran sebagai pembuat kebijakan dan koordinator program pemberdayaan serta pemberdayaan serta pembinaan sumberdaya Manusia, penyediaan sarana dan prasarana serta penyeluhan dan pengembangan pariwisata. Tokoh masyarakat (kepala Desa) sebagai akselerator yang berperan sebagai pengelolaan fasilitas penunjang bagi pengunjung wisata. Swasta (Pengusaha) memiliki peran sebagai fasilitator dalam pengembangan pariwisata, swasta berkontribusi terhadap pembangunan fasilitas pelengkap objek wisata. Masyarakat berperan dalam pengamanan wilayah kawasan wisata maupun sebagai pengelola objek wisata serta pemanfaatan objek wisata di Kabupaten Kepulauan Sula.

\section{DAFTAR PUSTAKA}

Agung Rheza Fauzi, Amy Yayuk Sri Rahayu. 2019. "Collaborative Governance Penanganan Hiv Aids Di Provinsi Dki Jakarta." 7:1-11.

Catherine V. Morsink, Carol Chases Thomas and Vivian i.Correra, Interactive Timing : Colsultation and Collaboration in Special Programs, New York, Mc Millian Publishing Company, 1991, hal.6.

Dwiyanto, Agus, 2010. Manajemen Pelayanan Publik: Peduli, inklusif dan Kolaboratif. Yogyakarta. Gadjah Mada University Press. 
Deseve, Edward. 2007, Creating publik Value using managed networks. In R.S.Morse, T.F.Buss.C.M.Kinghorn. Transforming publik leadership for the 21st century (hal.203-220). Armonk, NY : M.E. Sharpe

Emerson, krik et.al. 2011. An Integrative Framework for Collaborative Governance. Journal of Publik Administration research and Theory. JPART 22: 1-29.

Emzir. 2016. Metodologi Penelitian Kualitatif Analisis Data, Depok: Rajawali Perss.

Fawwaz Aldi Tilano, Sri Suwitri. 2019. "Collaborative Governance Dalam Upaya Keselamatan Lalu Lintas Dan Angkutan Jalan Di Kota Semarang." 1-18.

John W. Creswell. 2010. Research Design Pendekatan Kualitatif, Kuantitatif, dan Mixed. Edisi ke-3. Yogyakarta : Pustaka Pelajar.

Jhon Wanna, 2008. Collaborative Governance, A New era of publik policy in Australia?, Collaborative Government : meanings, dimensions, drivers and Outcome, edited by janine O'Flynn and John Wanna ANU Perss, Australia, (hal.3).

Kurniasih, Denok, Paulus Israwan Setyoko, And Moh Imron. 2017. "Collaborative Governance Dalam Penguatan Kelembagaan Program Sanitasi Lingkungan Berbasis Masyarakat (Slbm) Di Kabupaten Banyumas." 19(1):1-7.

Lexy J. Moleong, 2012. Metode Penelitian Kualitatif Edisi Revisi. Bandung: PT Remaja Rosdakarya.

Muhammad Ali,Amil, Zulhadi. 2018. "Implementasi Kebijakan Collaborative Governance Dalam Daerah Kabupaten Lombok Utara." 22(1):6-12.

Nazir, 2005. Metode Penelitian, Bogor Selatan: Ghalia Indonesia
Putra, Dimas Adi. 2018. "Collaborative Governance Dalam Pengelolaan Obyek Wisata Goa Pindul." 1-35.

Sigiono, 2012, Metode Penelitian Kuantitatif Kualitatif dan R\&D, Alfabeta, Bandung.

Sukardi, 2009, Metode Penelitian Pendidikan : Kompetensi dan Praktiknya, PT Bumi Aksara, Jakarta.

Sudarmo. 2009, Elemen-Elemen Collaboration Leadership dan Hambatan-Hambatan Bagi Pencapaian Efektifitas Collaboration Governance, Jurnal Spirit Publik. Vol.15, no.2, hlm: 117-132,ISSN 1907-0489

2011. Isu-isu Administrasi Publik dalam Perspektif Governance. Solo: Smart Media.

Soekadijo, R. G, 2000, Anatomi Pariwisata, PT. Gramedia Pustaka Utama, Jakarta.

Sunaryo, B. 2013. Kebijakan Pembangunan Destinasi Pariwisata Konsep dan Aplikasi di Indonesia. Yogyakarta: Gava Media

Suwantoro, Gamal, 1997. Dasar-dasar Pariwisata. ANDY. Yogyakarta.

2004. Dasar-Dasar

Pariwisata. ANDY. Yogyakarta.

Undang-Undang Nomor 23 Tahun 2014, tentang Pemerintahan Daerah.

Undang-Undang Nomor 10 Tahun 2009, tentang Kepariwisataan.

Wahyudi, Agustinus Sri, 1996, Manajemen Strategik: Pengantar Proses Berpikir Strategik, Binarupa Aksara, Jakarta.

Yoeti, Oka, A, 1996. Pemasaran Pariwisata, Angkasa, Bandung.

1997. Perencanaan dan Pengembangan Peristiwa, PT. Pradnya Paramita, Jakarta.

2002. Perencanaan Strategis Pemasaran Daerah Tujuan Wisata, PT. Pradnya Paramita, Jakarta. 